\title{
Short communication: The effect of delayed colostrum feeding on plasma concentrations of glucagon-like peptide 1 and 2 in newborn calves
}

\author{
Y. Inabu, ${ }^{*}$ A. Fischer, $†$ Y. Song, $†$ L. L. Guan, $\dagger$ M. Oba, $\dagger$ M. A. Steele, $\dagger^{1}$ and T. Sugino*1 \\ *The Research Center for Animal Science, Graduate School of Biosphere Science, Hiroshima University, Higashi-Hiroshima, Japan 739-8528 \\ †Department of Agricultural, Food and Nutritional Science, University of Alberta, Edmonton, Canada T6G 2P5
}

\begin{abstract}
Glucagon-like peptide (GLP)-1 is involved in glucose homeostasis via its role in stimulating insulin secretion, whereas GLP-2 increases mucosal growth of the small intestine. To our knowledge, the effect of delayed colostrum feeding on plasma GLP-1 and GLP-2 in neonatal calves has not been evaluated. To investigate the effect of delayed colostrum feeding on plasma concentrations of GLP-1 and GLP-2 in newborn calves, we randomly assigned 27 Holstein bull calves to 1 of 3 treatment groups: those fed colostrum within $1 \mathrm{~h}$ after birth (control), $6 \mathrm{~h}$ after birth $(6 \mathrm{H})$, and $12 \mathrm{~h}$ after birth (12H; $\mathrm{n}=9$ for each treatment). Blood samples were obtained before the colostrum feeding and every $3 \mathrm{~h}$ after each colostrum feeding for a $36-\mathrm{h}$ period, and plasma concentrations of GLP-1, GLP-2, insulin, and glucose were measured. Plasma GLP-1 concentration at $12 \mathrm{~h}$ after colostrum feeding was lower in $12 \mathrm{H}$ than in control calves. In addition, plasma insulin concentration was lower in the $6 \mathrm{H}$ and $12 \mathrm{H}$ calves than in the controls. Plasma glucose and GLP-2 concentrations were, however, not affected by treatment. These results indicate that delayed colostrum feeding can decrease plasma GLP-1 and insulin concentrations without affecting glucose or GLP-2 concentration.

Key words: gut-derived peptide, glucagon-like peptide 1, glucagon-like peptide 2 , colostrum
\end{abstract}

\section{Short Communication}

It is well known that timing of the first colostrum feeding is critical in the transfer of passive immunity in newborn calves, because the efficiency of $\operatorname{IgG}$ absorption decreases over the first 24 to $30 \mathrm{~h}$ of life (Bush and Staley, 1980; Weaver et al., 2000). More specifically, Osaka et al. (2014) reported that the apparent effi-

Received January 8, 2018.

Accepted March 6, 2018.

${ }^{1}$ Corresponding authors: masteele@ualberta.ca and sugino@ hiroshima-u.ac.jp ciency of IgG absorption declined by less than $0.3 \% / \mathrm{h}$ from calving to $12 \mathrm{~h}$ after birth, and then declined more rapidly at $2.5 \% / \mathrm{h}$ to at least $18 \mathrm{~h}$ after birth. Similar to blood IgG concentrations, plasma concentration of hormones, such as IGF-1 and insulin, were also reported to decrease with a delay in colostrum feeding (Hammon et al., 2000). These findings indicate that the timing of colostrum feeding could affect blood hormone concentrations, as well as the transfer of passive immunity.

Gut-derived peptides are known to play important roles in nutrient utilization and in the physical, morphologic, and metabolic transformation of growing animals. Among such peptides are glucagon-like peptide (GLP)-1 and GLP-2, which are co-secreted from enteroendocrine L-cells (mainly located in the distal intestine) in response to nutrient intake (Burrin et al., 2003). It has been reported that GLP-1 plays a role in glucose homeostasis via the stimulation of insulin secretion in both nonruminants (O'Halloran et al., 1990; Holz et al., 1993) and ruminants (Faulkner, 1991; Edwards et al., 1997; Fukumori et al., 2012), as well as through its own direct action without mediating insulin action (Luque et al., 2002; Acitores et al., 2005; Sancho et al., 2005, 2006). It has been reported that insulin, which is present at high concentrations in colostrum (Hammon et al., 2013), could be absorbed from intestine (Kirovski et al., 2008), indicating that exogenous insulin provided via colostrum feeding may contribute to circulating insulin concentration. On the other hand, Hammon et al. (2000) suggested that colostrum feeding increases endogenous insulin production in newborn calves. Therefore, given that plasma insulin concentration decreases with a delay in first colostrum feeding (Hammon et al., 2000), we speculate that delayed colostrum feeding may affect GLP-1 secretion as well as insulin in neonatal calves. On the other hand, GLP-2 plays a role in stimulating gastrointestinal tract (GIT) growth in ruminants (Taylor-Edwards et al., 2011), as well as nonruminants (Drucker et al., 1996; Kato et al., 1999; Hartmann et al., 2000). Major morphological and functional changes in the calf's GIT are initiated by colostrum feeding (Ontsouka et al., 2016), suggest- 
ing that GLP-2 can exert its action after feeding the calf with colostrum. However, the effects of colostrum feeding and delayed colostrum feeding on plasma GLP1 and GLP-2 concentrations have not been evaluated in newborn calves. Our objective in this study was to evaluate the effect of different delaying colostrum feeding on plasma concentrations of GLP-1 and GLP-2, as well as those of insulin and glucose.

All experimental procedures used in this study were approved by the University of Alberta Animal Care and Use Committee for Livestock (AUP00001595) and conducted in accordance with the guidelines of the Canadian Council of Animal Care (Ottawa, ON, Canada). A total of 27 Holstein bull calves were used for the present study. Calves were born as singlets, separated from their dams at birth, and then managed in individual pens. The pens in which calves were maintained were bedded with shavings on the bottom layer and fresh straw on the top. Calves were randomly assigned to 1 of 3 treatments: those fed pooled colostrum containing $62 \mathrm{~g}$ of IgG/L (Saskatoon Colostrum Company Ltd., Saskatoon, SK, Canada) at $7.5 \%$ of birth BW using an esophageal tube within $1 \mathrm{~h}$ after birth (control), $6 \mathrm{~h}$ after birth $(\mathbf{6 H})$, or $12 \mathrm{~h}$ after birth $(\mathbf{1 2 H} ; \mathrm{n}=9$ for each treatment). Birth BW was not different across treatment groups (means $\pm \mathrm{SD} ; 43.5 \pm 1.51 \mathrm{~kg}, 42.0 \pm$ $1.74 \mathrm{~kg}$, and $42.2 \pm 0.96 \mathrm{~kg}$ for control, $6 \mathrm{H}$, and $12 \mathrm{H}$, respectively). At $12 \mathrm{~h}$ after being fed colostrum and every $6 \mathrm{~h}$ thereafter, calves were fed milk replacer (MR; Excel Pro-Gro Calf Milk Replacer; Grober Nutrition, Cambridge, ON, Canada) at $2.5 \%$ of birth BW. Calves were fed MR by bottle initially, but if the calves did not consume all the MR within $30 \mathrm{~min}$, they were tube-fed the remainder of the MR volume. Colostrum was kept frozen at $-20^{\circ} \mathrm{C}$ until thawing and, before calving, the colostrum was thawed in a water bath at a constant temperature of $50^{\circ} \mathrm{C}$ until it reached a temperature of $39^{\circ} \mathrm{C}$. Similarly, MR was warmed to $39^{\circ} \mathrm{C}$ before feeding. Total protein, total fat, and lactose contents for colostrum were $14.2,5.0$, and $2.7 \%$, respectively, and $\mathrm{CP}$, crude fat, and lactose contents for MR were 26,18 , and $42 \%$, respectively. For all treatments, blood samples were taken within $1 \mathrm{~h}$ after birth (before colostrum feeding) using evacuated tubes (Fisher Scientific Co., Nepean, ON, Canada) as baseline samples and every 3 $\mathrm{h}$ after each colostrum feeding through a jugular catheter (Thermo Fisher Scientific, Carlsbad, CA), which was fitted at $2 \mathrm{~h}$ after birth, for a 36 -h period. The blood samples collected at 12, 18, 24, 30, and $36 \mathrm{~h}$ after colostrum feeding were taken immediately before MR feeding. Immediately after sample collection, aprotinin (Sigma Aldrich, Oakville, ON, Canada) was added to the blood samples for plasma preparation (in the ratio of $0.5 \mu \mathrm{L}$ of aprotinin to $1 \mathrm{~mL}$ of blood). Blood samples were centrifuged at $3,000 \times g$ and $4^{\circ} \mathrm{C}$ for $20 \mathrm{~min}$, and plasma was collected and stored at $-20^{\circ} \mathrm{C}$ until analysis.

Plasma samples were analyzed for hormone and glucose concentrations. Plasma hormone concentrations were measured following the time-resolved fluoroimmunoassay (TR-FIA) technique previously described by Sugino et al. (2004). Plasma GLP-1 concentration was measured using a solid-phase competition immunoassay with europium (Eu)-labeled human GLP-1 and polystyrene microtiter strips (Nalgene Nunc Int., Tokyo, Japan) coated with anti-rabbit $\gamma$-globulin (Inabu et al., 2017). Interassay coefficient of variation (CV) was $5.3 \%$, and the least detectable level was $0.007 \mathrm{ng} /$ $\mathrm{mL}$. Plasma GLP-2 concentration was measured using a solid-phase competition immunoassay with Eu-labeled human GLP-2 (Peptide Institute Inc., Osaka, Japan), polyclonal anti-rat GLP-2 (Yanaihara Institute Inc., Shizuoka, Japan), and polystyrene microtiter strips coated with goat-anti-rabbit $\gamma$-globulin (Inabu et al., 2017). Interassay CV was $5.8 \%$ and the least detectable level was $0.038 \mathrm{ng} / \mathrm{mL}$. The plasma concentration of insulin was measured using a solid-phase competition immunoassay with Eu-labeled bovine insulin and polystyrene microtiter strips coated with anti-guinea pig $\gamma$-globulin (Inabu et al., 2017). Interassay CV was $3.1 \%$, and the least detectable level was $0.14 \mathrm{ng} / \mathrm{mL}$. Plasma glucose concentration was analyzed using an enzymatic method with peroxidase glucose oxidase (Sigma, St. Louis, MO).

Data for plasma glucose, GLP-1, GLP-2, and insulin concentrations were analyzed using the fit model procedure of JMP 13 (SAS Institute Inc., Cary, NC) according to the following model:

$$
\mathrm{Y}_{\mathrm{ijk}}=\mu+\mathrm{T}_{\mathrm{i}}+\mathrm{H}_{\mathrm{j}}+\mathrm{C}_{\mathrm{k}}+\mathrm{TH}_{\mathrm{ij}}+\mathrm{e}_{\mathrm{ijk}},
$$

where $Y_{\mathrm{ijk}}$ is the dependent variable, $\mu$ is the overall mean, $T_{i}$ is the fixed effect of treatment, $H_{j}$ is the fixed effect of time after colostrum feeding used as a repeated measure, $\mathrm{C}_{\mathrm{k}}$ is the random effect of calf, $\mathrm{TH}_{\mathrm{ij}}$ is the interaction of treatment and time, and $\mathrm{e}_{\mathrm{ijk}}$ is the error term. All values were expressed as least squares means \pm standard errors of the means (LSM \pm SEM). The effects of treatment, time, and treatment by time interaction were considered significant at $P<0.05$ and tendencies were assumed at $0.05 \leq P<0.10$.

Although we observed a time effect on plasma glucose concentration $(P<0.01$; Figure $1 \mathrm{~A})$, this was mainly a result of the increased concentration after MR feeding, whereas we observed no increase up to $12 \mathrm{~h}$ after colostrum feeding. The small response of glucose to colostrum feeding was probably due to the lower lactose content in colostrum (only $2.7 \%$ in this study) 
compared with that in MR ( $42 \%$ in this study). We observed a treatment $\times$ time interaction for plasma glucose concentration $(P=0.02)$; however, this was a result of a higher concentration for the $6 \mathrm{H}$ calves $(92.7 \pm 10.5 \mathrm{mg} / \mathrm{dL})$ than for the control calves $(66.6$ $\pm 11.2 \mathrm{mg} / \mathrm{dL}$ ) at the initiation of this study and a lower concentration for $6 \mathrm{H}$ calves $(55.6 \pm 5.6 \mathrm{mg} /$ $\mathrm{dL})$ than $12 \mathrm{H}$ calves $(79.5 \pm 5.6 \mathrm{mg} / \mathrm{dL})$ at $3 \mathrm{~h}$ after colostrum feeding. We observed no difference between treatments thereafter. This finding may be attributed to individual variation rather than a treatment effect. Hammon et al. (2000) reported that energy status did not change markedly with delayed colostrum supply, as delayed colostrum feeding did not substantially affect plasma glucose concentrations, which is consistent with our results.

In this study, we showed for the first time that plasma GLP-1 and GLP-2 concentrations increase after feeding neonatal calves colostrum (Figure $1 \mathrm{~B}$ and $1 \mathrm{C}$; time: $P$ $<0.01)$. Due to the low concentrations of GLP in amniotic fluid and colostrum (pig model), and therefore the limited absorption of GLP from these exogenous fluids
(Petersen et al., 2003), we conclude that the increase in GLP-1 and GLP-2 concentrations after colostrum feeding may be due to the stimulation of endogenous production.

We also found that GLP-1 concentration at $12 \mathrm{~h}$ after colostrum feeding was lower (treatment $\times$ time $P=0.05)$ for the $12 \mathrm{H}(2.11 \pm 0.53 \mathrm{ng} / \mathrm{mL})$ than for the control $(3.37 \pm 0.53 \mathrm{ng} / \mathrm{mL})$ calves. This indicates that delayed colostrum feeding may decrease plasma GLP-1 concentration. As described above, GLP concentrations in amniotic fluid and colostrum may be low, and therefore the lower GLP-1 concentration for the $12 \mathrm{H}$ calves can likely be attributed to reduced secretion of GLP-1. As mentioned previously, GLP-1 stimulates insulin secretion; however, we observed no correlation between plasma GLP-1 and insulin concentrations ( $\mathrm{r}=$ $-0.07, P=0.20)$. Further, although GLP-1 concentration increased in response to colostrum feeding in all treatments, we observed an increase in plasma insulin concentration up to $12 \mathrm{~h}$ after colostrum feeding only for the control calves (time: $P<0.01$ ). In addition, the insulinotropic action of GLP-1 is glucose dependent
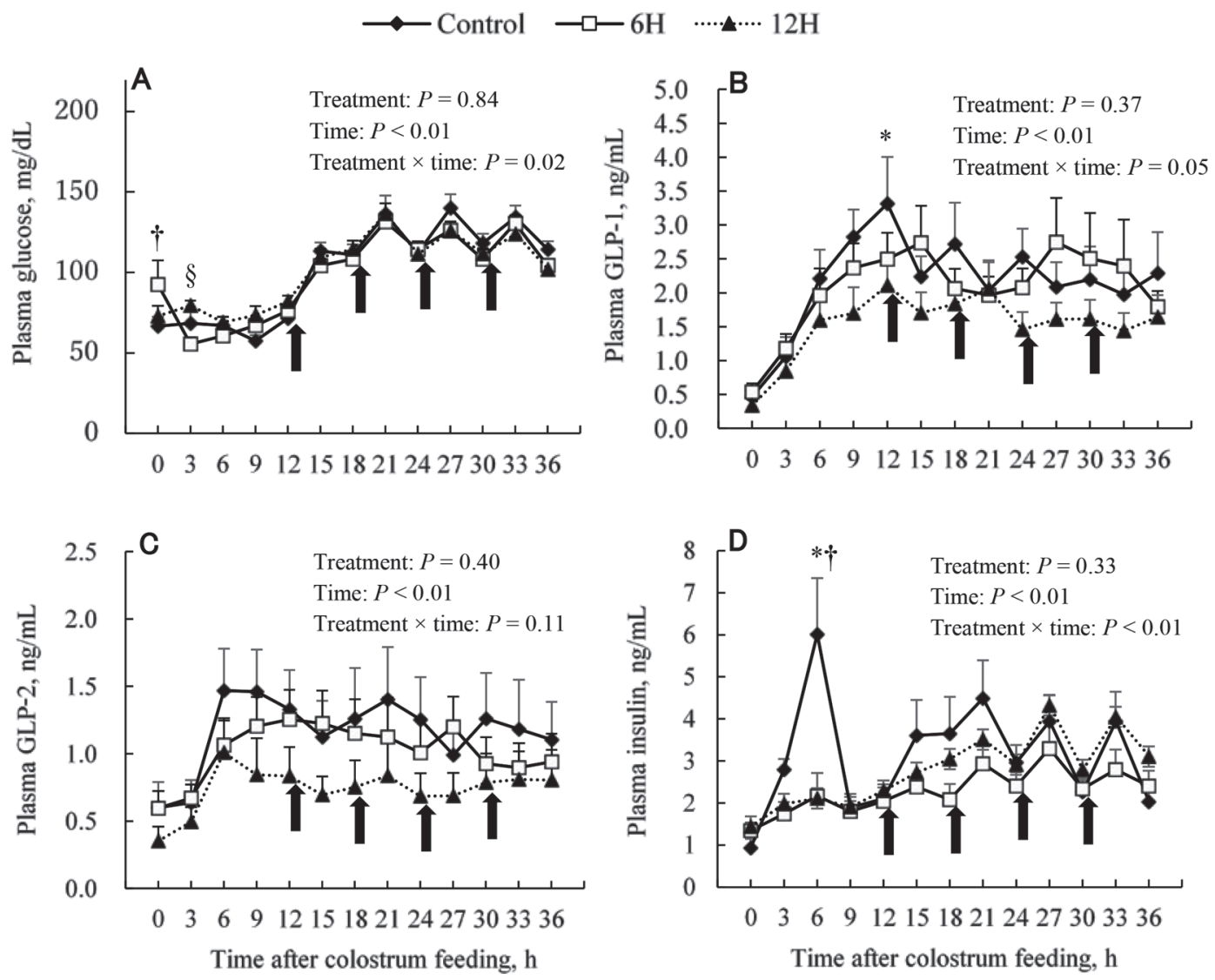

Figure 1. Plasma concentrations (LSM $\pm \mathrm{SEM}$ ) of glucose (A; mg/dL), and glucagon-like peptide (GLP)-1 (B), GLP-2 (C), and insulin (D; $\mathrm{ng} / \mathrm{mL}$ ) for calves fed colostrum within $1 \mathrm{~h}$ after birth (control), $6 \mathrm{~h}$ after birth $(6 \mathrm{H})$, and $12 \mathrm{~h}$ after birth (12H). Significant difference between $\dagger$ control and $6 \mathrm{H}$ groups; $*$ control and $12 \mathrm{H}$ groups; $\S 6 \mathrm{H}$ and $12 \mathrm{H}$ groups. Arrow indicates milk replacer feeding. 
(Stygar et al., 2018), and we observed no increase in glucose concentration in response to colostrum feeding in any of the treatments. Therefore, the increase in insulin concentration in response to colostrum feeding may not be primarily a consequence of GLP-1 action. Insulin is present in high concentration in bovine colostrum (Hammon et al., 2013), and Kirovski et al. (2008) reported that insulin administered orally to calves within 30 min after birth was absorbed from the intestine, indicating that colostral insulin can be absorbed immediately after birth in calves. On the other hand, Weaver et al. (2000) reported that gut closure occurs within approximately $24 \mathrm{~h}$ postpartum. This indicates that the lack of increase in insulin concentrations for the $6 \mathrm{H}$ and $12 \mathrm{H}$ groups may have resulted from decreased absorption of colostral insulin from the intestine by the initiation of gut closure. In addition, plasma insulin concentration at $6 \mathrm{~h}$ after colostrum feeding was lower (treatment $\times$ time: $P<0.01$ ) for $6 \mathrm{H}(2.17 \pm 0.84 \mathrm{ng} / \mathrm{mL})$ and $12 \mathrm{H}(2.11 \pm 0.84 \mathrm{ng} /$ $\mathrm{mL})$ groups than for the control $(6.01 \pm 0.84 \mathrm{ng} / \mathrm{mL})$, which might be attributed to the lack of increase in insulin concentration as described above. Hammon et al. (2000) reported that plasma insulin concentration decreased with a delay in first colostrum feeding, which is consistent with the findings of the present study. An increase in plasma insulin concentration might stimulate anabolic processes in muscle and fat tissue, leading to enhanced tissue growth in intensively milk-fed calves (Schäff et al., 2016). Thus, we suggest that delayed colostrum feeding may negatively affect growth via a decreased insulin concentration in newborn calves and warrants further investigation.

The observed fluctuation in postprandial GLP-2 concentration was similar to that of GLP-1. Both GLP-1 and GLP-2 are co-secreted from the intestinal L-cells in both nonruminants (Burrin et al., 2003) and ruminants (Elsabagh et al., 2017; Inabu et al., 2017). In the present study, we detected a positive correlation between GLP-1 and GLP-2 over the 36 -h period after colostrum feeding $(\mathrm{r}=0.49 \mathrm{P}<0.01$; Figure 2), which indicates that GLP-1 and GLP-2 may be co-secreted in neonatal calves. In the present study, plasma GLP-2 concentration increased in response to colostrum feeding, and thus it is possible that GLP-2 is involved in GIT development after colostrum feeding in neonatal calves. The effects of treatment and treatment $\times$ time interaction were not observed for plasma GLP-2 concentration, despite the fact that GLP-2 is co-secreted with GLP-1 in an equal ratio from the same cells (Burrin et al., 2003; Connor et al., 2015). Although the half-life of GLP-2 is different from that of GLP-1 (Janssen et al., 2013), the reason for the lack of difference in GLP-2 between treat-

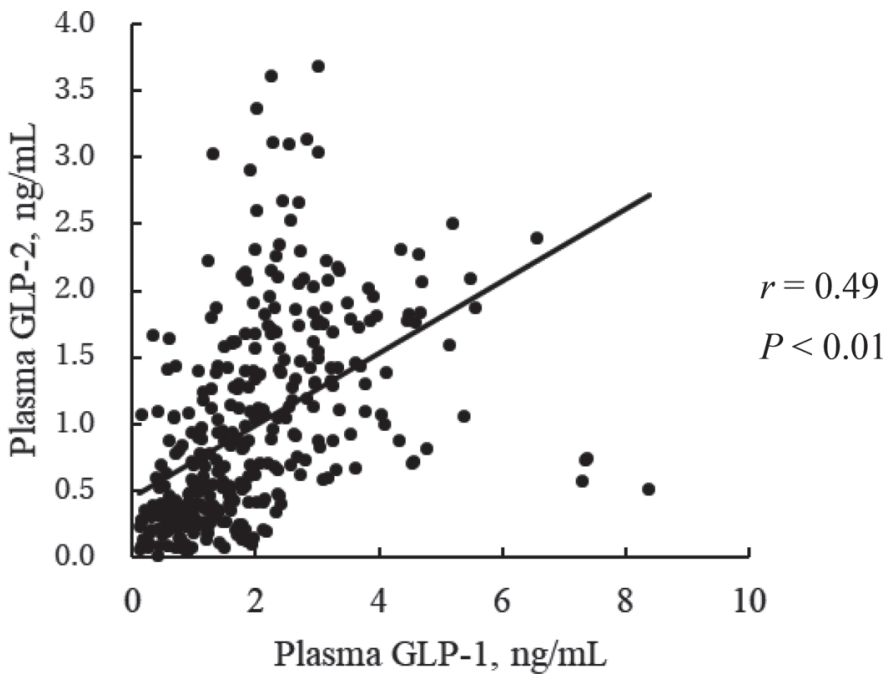

Figure 2. Pearson correlation coefficients between the plasma concentrations of glucagon-like peptide (GLP)-1 and GLP-2 for the 36-h period after colostrum feeding.

ments is not known. However, it is possible that GLP-2 secretion was reduced by delayed colostrum feeding without a change in plasma concentration. It has been reported that secretion of GLP-2 from intestinal L-cells may be inhibited by elevated local concentrations of GLP-2 through a negative feedback loop (Connor et al., 2015). Therefore, given that GLP-2 secretion was suppressed in the $6 \mathrm{H}$ and $12 \mathrm{H}$ groups, it is possible that GLP-2 secretion is inhibited by its high concentration in the control group.

In conclusion, the results from this study indicate that delayed colostrum feeding may decrease GLP-1 and insulin concentrations and, as such, a delay in colostrum feeding could negatively affect the growth of newborn calves. In contrast, plasma glucose and GLP-2 concentrations were not affected by delayed colostrum feeding. These results extend our understanding of the effects of timing colostrum feeding on the secretion of gut-derived peptides and may have implications for the improvement of calf performance.

\section{ACKNOWLEDGMENTS}

The authors thank the funding support provided by Alberta Livestock and Meat Agency Ltd. (Edmonton, AB, Canada), Alberta Milk (Edmonton, AB, Canada), The Saskatoon Colostrum Co. Ltd. (Saskatoon, SK, Canada), and the Natural Sciences and Engineering Research Council of Canada (Moncton, NB, Canada). The authors also thank the staff of the Dairy Research and Technology Centre (University of Alberta) for their assistance with the animal experiment. 


\section{REFERENCES}

Acitores, A., N. González, V. Sancho, L. Arnés, I. Valverde, W. J. Malaisse, and M. L. Villanueva-Peñacarrillo. 2005. Participation of protein kinases in the stimulant action of GLP-1 on 2-deoxy-Dglucose uptake by normal rat skeletal muscle. Horm. Metab. Res. $37: 275-280$.

Burrin, D. G., B. Stoll, and X. Guan. 2003. Glucagon-like peptide 2 function in domestic animals. Domest. Anim. Endocrinol. 24:103122.

Bush, L. J., and T. E. Staley. 1980. Absorption of colostral immunoglobulins in newborn calves. J. Dairy Sci. 63:672-680.

Connor, E. E., C. M. Evock-Clover, M. P. Walker, T. H. Elsasser, and S. Kahl. 2015. Comparative physiology of glucagon-like peptide-2: Implications and applications for production and health of ruminants. J. Anim. Sci. 93:492-501.

Drucker, D. J., P. Erlich, S. L. Asa, and P. L. Brubaker. 1996. Induction of intestinal epithelial proliferation by glucagon-like peptide 2 . Proc. Natl. Acad. Sci. USA 93:7911-7916.

Edwards, C. M. B., A. V. Edwards, and S. R. Bloom. 1997. Cardiovascular and pancreatic endocrine responses to glucagon-like peptide-1 (7-36) amide in the conscious calf. Exp. Physiol. 82:709-716.

Elsabagh, M., Y. Inabu, T. Sugino, and T. Obitsu. 2017. Response of plasma glucagon-like peptide-2 to feeding pattern and intraruminal administration of volatile fatty acids in sheep. Domest. Anim. Endocrinol. 60:31-41.

Faulkner, A. 1991. Sensitivity of serum insulin concentrations to glucagon-like peptide 1 (7-36) amide in sheep. Biochem. Soc. Trans. 19:311S.

Fukumori, R., T. Mita, T. Sugino, T. Obitsu, and K. Taniguchi. 2012. Plasma concentrations and effects of glucagon-like peptide-1 (736) amide in calves before and after weaning. Domest. Anim. Endocrinol. 43:299-306.

Hammon, H. M., J. Steinhoff-Wagner, J. Flor, U. Schönhusen, and C. C. Metges. 2013. Role of colostrum and colostrum components on glucose metabolism in neonatal calves. J. Anim. Sci. 91:685-695.

Hammon, H. M., I. A. Zanker, and J. W. Blum. 2000. Delayed colostrum feeding affects IGF-I and insulin plasma concentrations in neonatal calves. J. Dairy Sci. 83:85-92.

Hartmann, B., J. Thulesen, H. Kissow, S. Thulesen, C. Orskov, C. Ropke, S. S. Poulsen, and J. J. Holst. 2000. Dipeptidylpeptidase IV inhibition enhances the intestinotrophic effect of glucagon-like peptide 2 in rats and mice. Endocrinology 141:4013-4020.

Holz, G. G. IV, W. M. Kühtreiber, and J. F. Habener. 1993. Pancreatic beta-cells are rendered glucose-competent by the insulinotropic hormone glucagon-like peptide-1(7-37). Nature 361:362-365.

Inabu, Y., A. Saegusa, K. Inouchi, S. Koike, M. Oba, and T. Sugino. 2017. Plasma concentrations of glucagon-like peptide 1 and 2 in calves fed calf starters containing lactose. J. Dairy Sci.101:93619371. https://doi.org/10.3168/jds.2017-12910. PubMed

Janssen, P., A. Rotondo, F. Mule, and J. Tack. 2013. Review article: A comparison of glucagon-like peptides 1 and 2. Aliment. Pharmacol. Ther. 37:18-36.

Kato, Y., D. H. Yu, and M. Schwartz. 1999. Glucagon-like peptide 2 enhances small intestinal absorptive function and mucosal mass in vivo. J. Pediatr. Surg. 34:18-20.

Kirovski, D., M. Lazarević, I. Baricević-Jones, O. Nedić, R. Masnikosa, and J. A. Nikolie. 2008. Effects of peroral insulin and glucose on circulating insulin-like growth factor-1, its binding proteins and thyroid hormones in neonatal calves. Can. J. Vet. Res. 72:253-258.

Luque, M. A., N. González, L. A. Márquez Acitores, A. Redondo, M. Morales, I. Valverde, and M. L. Villanueva-Peñacarrillo. 2002. Glucagon-like peptide-1 (GLP-1) and glucose metabolism in human myocytes. J. Endocrinol. 173:465-473.

O'Halloran, D. J., G. C. Nikou, B. Kreymann, M. A. Ghatei, and S. R. Bloom. 1990. Glucagon like peptide-1 (7-36)-NH2: A physiological inhibitor of gastric acid secretion in man. J. Endocrinol. 126:169-173.

Ontsouka, E. C., C. Albrecht, and R. M. Bruckmaier. 2016. Growthpromoting effects of colostrum in calves based on interaction with intestinal cell surface receptors and receptor-like transporters. J. Dairy Sci. 99:4111-4123.

Osaka, I., Y. Matsui, and F. Terada. 2014. Effect of the mass of immunoglobulin (Ig) G intake and age at first colostrum feeding on serum IgG concentration in Holstein calves. J. Dairy Sci. 97:66086612.

Petersen, Y. M., B. Hartmann, J. J. Holst, I. Le Huerou-Luron, C. R. Bjørnvad, and P. T. Sangild. 2003. Introduction of enteral food increases plasma GLP-2 and decreases GLP-2 receptor mRNA abundance during pig development. J. Nutr. 133:1781-1786.

Sancho, V., M. V. Trigo, N. González, I. Valverde, W. J. Malaisse, and M. L. Villanueva-Peñacarrillo. 2005. Effects of glucagon-like peptide- 1 and exendins on kinase activity, glucose transport and lipid metabolism in adipocytes from normal and type-2 diabetic rats. J. Mol. Endocrinol. 35:27-38.

Sancho, V., M. V. Trigo, A. Martín-Duce, N. Gonzalez, A. Acitores, L. Arnés, I. Valverde, W. J. Malaisse, and M. L. Villanueva-Penacarrillo. 2006. Effect of GLP-1 on D-glucose transport, lipolysis and lipogenesis in adipocytes of obese subjects. Int. J. Mol. Med. 17:1133-1137.

Schäff, C. T., J. Gruse, J. Maciej, M. Mielenz, E. Wirthgen, A. Hoeflich, M. Schmicke, R. Pfuhl, P. Jawor, T. Stefaniak, and H. M. Hammon. 2016. Effects of feeding milk replacer ad libitum or in restricted amounts for the first five weeks of life on the growth, metabolic adaptation, and immune status of newborn calves. PLoS One 11:e0168974.

Stygar, D., T. Sawczyn, B. Skrzep-Poloczek, A. J. Owczarek, N. Matysiak, M. Michalski, Ł. Mielańczyk, B. Bażanów, P. Ziora, P. Choręza, B. Doleżych, and K. W. Karcz. 2018. The effects of duodenojejunal omega switch in combination with high-fat diet and control diet on incretin, body weight, and glucose tolerance in Sprague-Dawley rats. Obes. Surg. 28:748-759. https://doi.org/10 .1007/s11695-017-2883-3.

Sugino, T., Y. Hasegawa, Y. Kurose, M. Kojima, K. Kangawa, and Y. Terashima. 2004. Effects of ghrelin on food intake and neuroendocrine function in sheep. Anim. Reprod. Sci. 82-83:183-194.

Taylor-Edwards, C. C., D. G. Burrin, J. J. Holst, K. R. McLeod, and D. L. Harmon. 2011. Glucagon-like peptide-2 (GLP-2) increases small intestinal blood flow and mucosal growth in ruminating calves. J. Dairy Sci. 94:888-898.

Weaver, D. M., J. W. Tyler, D. C. VanMetre, D. E. Hostetler, and G. M. Barrington. 2000. Passive transfer of colostral immunoglobulins in calves. J. Vet. Intern. Med. 14:569-577. 